V Seminário Anual Científico e Tecnológico | Bio-Manguinhos

\title{
REA 13 - Desenvolvimento e padronização de ensaio molecular para a detecção de vírus Mayaro
}

Marcela Fontana $^{1 *}$; Elisabete Andrade ${ }^{1}$; Marisa Ribeiro ${ }^{1}$; Daniele Rocha ${ }^{1}$; Elaine Costa $^{1}$;

Sthefanie Ribeiro ${ }^{1}$; Daniela T. Godoy ${ }^{1}$; Antonio G. P. Ferreira ${ }^{1}$; Patrícia Alvarez ${ }^{1}$.

1 Bio-Manguinhos / Fiocruz.

\section{Introdução:}

O vírus Mayaro (MAYV) é um arbovírus pertencente ao gênero Alphavirus da família Togaviridae. A febre do Mayaro é uma zoonose silvestre transmitida por mosquitos, especialmente pelas picadas do Haemagogus janthinomys, que também transmite a febre amarela. Ensaios em laboratório já demonstraram que os mosquitos Aedes aegypti e Aedes albopictus podem ser vetores do Mayaro. O fato de viverem próximos do homem e de se adaptarem facilmente ao ambiente urbano representa risco maior de se tornarem vetores envolvidos na disseminação da infecção pelo MAYV. Os sintomas da doença são muito parecidos com os da Dengue e da febre Chikungunya, o que dificulta o diagnóstico baseado na análise do quadro clínico.

\section{Objetivo:}

Padronizar ensaio para diagnóstico molecular para detecção dos vírus Mayaro na plataforma de PCR em Tempo Real.

\section{Metodologia:}

Os iniciadores e sonda utilizados na padronização do ensaio estão localizados na região conservada, nsP1. Em toda reação é utilizada uma partícula calibradora (PC), como controle interno do sistema. Até o momento, para a padronização da concentração de sonda e iniciadores, e para obtenção das provas de conceito, foram processadas amostras de cultura desse vírus.

\section{Resultado:}

O processamento das amostras de cultivo do MAYV demonstrou resultados significativos, apresentando um bom desempenho das curvas de amplificação de MAYV e da PC, em uma mesma reação. Os testes de especificidade e reação cruzada foram realizados com amostras verdadeiras negativas e com outros arbovírus como, Zika e Chikungunya, e não apresentaram amplificação inespecífica e nem reação cruzada com 
os outros arbovírus. Em testes preliminares, obtivemos MAY VIC e PC DYE3, como a combinação das fluorescências. As extrações de vírus de cultura de Mayaro foram feitas em sistemas automatizados de extração, em coluna de sílica ou com partículas magnéticas.

\section{Conclusão:}

Os testes realizados mostraram que a reação duplex, por PCR em tempo real, para Mayaro

e PC é satisfatória. A padronização do ensaio descrito foi realizada com amostras de cultura. Entretanto, para a validação do sistema há necessidade de testes frente a amostras clínicas positivas, além de estudos de avaliação da metodologia, os quais definirão as características técnicas, como os níveis de sensibilidade, reprodutibilidade, especificidade entre outros.

Palavras-chave: Vírus Mayaro; Diagnóstico; PCR em tempo real 